\title{
ANALISIS PENGARUH PRODUK, HARGA, DAN TEMPAT TERHADAP KEPUTUSAN PEMBELIAN (Studi Kasus Pada Wisata Kuliner Pantai Jempol Labuhan Sumbawa)
}

\author{
HAEDIR \\ Fakultas Ekonomi dan Bisnis, Jurusan Manajemen \\ Universitas Teknologi Sumbawa \\ e-mail: jeckyhaedir96@gmail.com
}

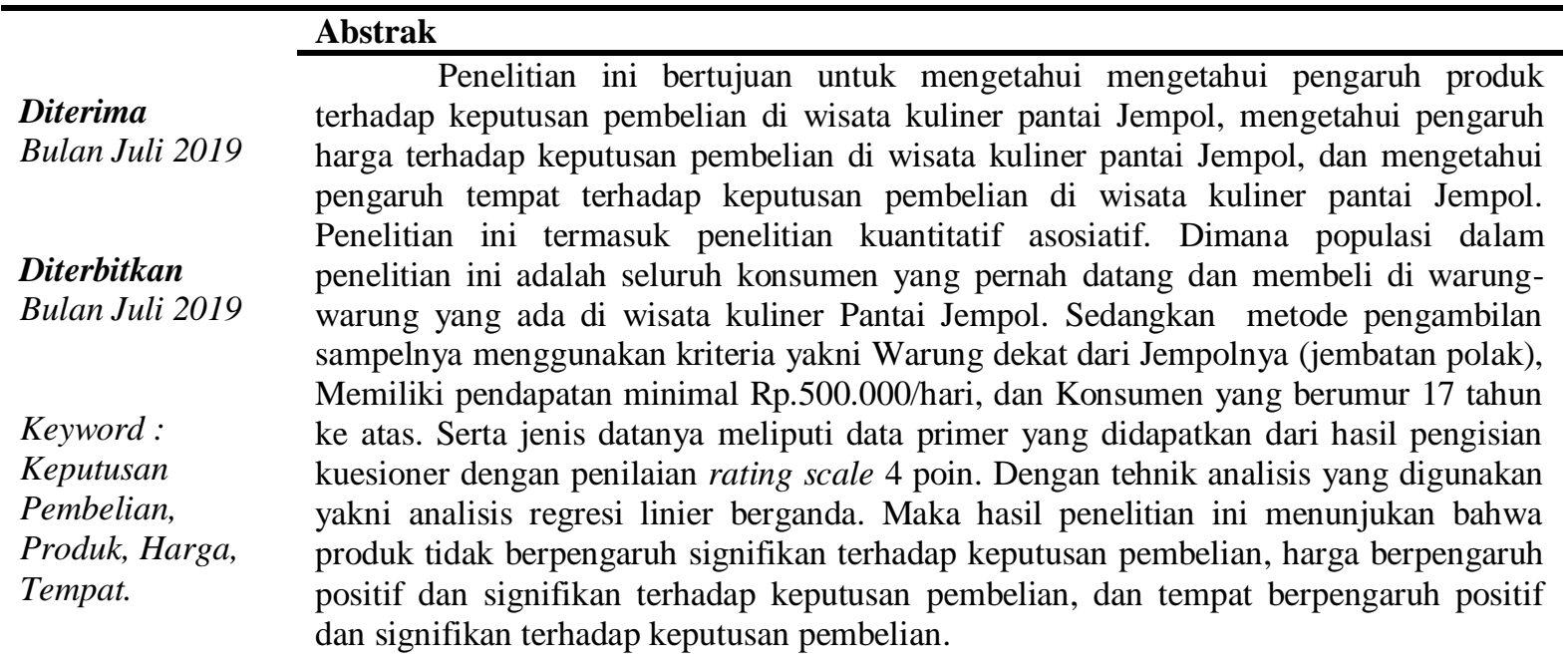

\section{PENDAHULUAN}

\section{Latar Belakang}

Pada era bisnis saat ini, persaingan dalam dunia bisnis semakin bertambah ketat, persaingan yang semakin ketat ini menuntut para pelaku bisnis untuk mampu memaksimalkan kinerja perusahaannya agar dapat bersaing di pasar, demikian dikatakan Kotler dan Keller (2009:19) mengatakan bahwa "konsumen lebih menyukai produk yang tersedia dalam jumlah banyak dan tidak mahal, dan jika konsumen tidak memiliki pengalaman dengan suatu produk, mereka cenderung untuk mempercayai merek yang disukai atau yang terkenal".

Menurut Kotler dan Keller, (2009: 11) perusahaan umumnya membentuk departemen pemasaran guna bertanggung jawab serta menciptakan nilai kepada pelanggan, dan harus menempatkan orientasi pada kepuasan konsumen sebagai tujuan utama. Kunci utama perusahaan untuk memenangkan persaingan adalah memberikan nilai dan kepuasan kepada konsumen melalui penyampaian produk dan jasa yang berkualitas dengan harga yang bersaing, karena harga yang bersaing juga dapat memengaruhi pelanggan dalam keputusan pembelian.
Keputusan pembelian adalah suatu proses penyelesaian masalah yang terdiri dari menganalisa atau pengenalan kebutuhan dan keinginan, pencarian informasi, penilaian sumber-sumber seleksi terhadap alternatif pembelian, keputusan pembelian, dan perilaku setelah pembelian (Kotler dan Keller, 2009:251) Dalam hal ini produk juga berpengaruh terhadap keputusan pembelian dalam suatu perusahaan atau tempat bisnis lainnya.

Perusahaan harus dapat memasarkan barang atau jasa yang diproduksi kepada konsumen agar dapat bertahan dan bersaing dengan perusahaan lain. Menurut (Kotler dan Keller, 2009:4), "produk adalah segala sesuatu yang dapat ditawarkan kepada pasar untuk memuaskan suatu keinginan atau kebutuhan, termasuk barang fisik, jasa, pengalaman, acara, orang, tempat, properti, informasi, dan ide". Perusahaan dengan produk yang paling baik akan tumbuh dengan pesat, dan dalam jangka panjang perusahan tersebut akan lebih berhasil dari perusahaan yang lain. Menurut Gitosudarmo, (2000:117) Segala sesuatu yang dianggap dapat memenuhi kebutuhan manusia, dimana produk sangat berpengaruh terhadap keputusan pembelian, karena konsumen 
melihat kualitas produk tersebut dapat memenuhi kebutuhan serta keinginannya, sehingga kualitas produknya sesuai dengan harga yang diberikan.

Menurut Kotler dan Keller (2007:77), "harga adalah segala bentuk biaya moneter yang dikorbankan oleh konsumen untuk memperoleh dan memanfaatkan sejumlah kombinasi dari barang beserta pelayanan dari suatu produk". Perusahaan harus menetapkan harga jual untuk yang pertama kalinya, terutama pada saat mengembangkan produk baru.

Penetapan harga jual berpotensi menjadi suatu masalah karena keputusan penetapan harga jual cukup kompleks dan harus memperhatikan berbagai aspek yang memengaruhinya. Faktor harga berpengaruh terhadap keputusan pembelian, dimana konsumen melihat kesesuaian harga dengan kualitas produk yang diinginkan (Kodu, 2013). Selain itu, faktor lokasi juga berpengaruh terhadap penetapan harga produk, apabila lokasi bisnis strategis, harga produk pun meningkat.

Pemilihan lokasi yang baik, merupakan keputusan yang sangat penting, karena keputusan lokasi mempunyai dampak yang permanen dan jangka panjang, apakah lokasi tersebut telah dibeli atau hanya disewa, dan jika lokasi telah dibeli maka jangka panjang terhadap pendapatannya yang dihasilkan juga besar, dan lokasi tersebut hanya disewa maka jangka panjang terhadap pendapatan terhadap lokasi tersebut lebih kecil karena masih mengeluarkan biaya untuk pembayaran bulanan untuk lokasi yang disewa (Ligia dkk, 2014). Lokasi yang dipilih haruslah mampu membuat usahanya mengalami pertumbuhan sehingga dapat bertahan lama. Jika nilai lokasi memburuk akibat perubahan lingkungan yang dapat terjadi setiap waktu, kemungkinan usaha tersebut harus dipindahkan atau ditutup.

Sebuah pantai yang berlokasi di Labuhan Sumbawa, Jembatan Polak atau biasa dikenal dengan sebutan "JEMPOL". Inilah nama yang sering disebut-sebut oleh para remaja atau para pegawai-pegawai kantoran untuk datang sekedar bersantai duduk dengan minuman atau berbagai hidangan dan menu yang bervariasi serta memiliki harga yang sangat terjangkau yang akan kita temui disana, dan sambil menikmati keindahan pemandangan laut, serta matahari tenggelam jika disore hari. Saat ini wisata kuliner pantai Jempol sangat maraknya diminati oleh pengunjung atau masyarakat Sumbawa. Pengunjung datang bukan hanya diwaktu siang dan sore hari, tetapi pengunjung juga datang diwaktu malam hari juga.

Berdasarkan uraian di atas, maka peneliti tertarik untuk melakukan penelitian dengan judul "Analisis Pengaruh Produk, Harga, dan Tempat Terhadap Keputusan Pembelian (Studi Kasus Pada Wisata Kuliner Pantai Jempol Labuhan Sumbawa)".

\section{Rumusan Masalah}

Dalam penelitian ini permasalahan yang dihadapi dalam proses penelitian dapat dirumuskan sebagai berikut:

1. Bagaimana pengaruh produk terhadap keputusan pembelian di wisata kuliner pantai Jempol ?

2. Bagaimana pengaruh harga terhadap keputusan pembelian di wisata kuliner pantai Jempol ?

3. Bagaimana pengaruh tempat terhadap keputusan pembelian di wisata kuliner pantai Jempol?

\section{Hipotesis Penelitian}

Berdasarkan rumusan masalah di atas, bahwa variabel bebas berpengaruh terhadap variabel terikat, maka hipotesis penelitian yang diajukan dalam penelitian ini adalah sebagai berikut :

1. $\mathrm{H}_{1}$ : Variabel produk berpengaruh signifikan terhadap keputusan pembelian.

2. $\mathrm{H}_{2}$ : Variabel harga berpengaruh signifikan terhadap keputusan pembelian.

3. $\mathrm{H}_{3}$ : Variabel tempat berpengaruh signifikan terhadap keputusan pembelian

\section{LANDASAN TEORI}

\section{Bauran Pemasaran}

Bauran pemasaran adalah 4P, yaitu product, price, place, and promotion, (produk, harga, tempat, dan promosi) dimana dapat membuat minat serta kebutuhan terhadap pelanggan atau konsumen (Payne, 2007:155). Bauran pemasaran adalah proses perencanaan dan pelaksanaan konsepsi, penetapan produk, harga, promosi, dan distribusi gagasan barang dan jasa untuk menciptakan pertukaran yang memuaskan tujuan individu dan organisasi (Kotler \& Keller, 2009:38).

Berikut beberapa penjelasan indikatorindikator dari varibel bebas dan variabel terikat.

\section{Produk}

Produk dapat didefinisikan sebagai persepsi konsumen yang dijabarkan oleh produsen melalui hasil produksinya atau hasil produksi yang meliputi konsep total. Produk dipandang penting oleh konsumen dan dijadikan dasar pengambilan keputusan. "Produk merupakan suatu barang nyata yang 
dapat terlihat atau berwujud dan bahkan dapat dipegang yang dirancang untuk memuaskan keinginan atau kebutuhan konsumen seperti komputer, mobil, alat gosok gigi, makanan, dan lain-lain" (Malau, 2016:31).

Adapun indikator dari variabel produk menurut Tjiptono, (2010:67) sebagai berikut:

a. Keistimewaan produk (features)

Pada hakekatnya seseorang membeli produk bukan hanya sekedar ia ingin memiliki produk. Para konsumen membeli barang karena barang tersebut memiliki keistimewaan dan citra produk yang baik agar kepuasan konsumen terpenuhi dari produk yang di belinya.

b. Kesesuaian keinginan

Secara umum pelaku bisnis atau usaha selalu menyediakan berbagai macam variasi terhadap produknnya agar dapat mencapai target dan sesuai dengan yang diinginkan konsumen atau pelanggan.

c. Estetika

Estetika adalah daya tarik produk terhadap panca indra (dari segi aroma, rasa, daya tarik penglihatanatau dari segi penampilan produk) konsumen atau pelanggan, dimana produk tersebut memiliki kesan atau varian rasa berbeda yang membuat konsumen tertarik terhadap produk tersebut. yang diterima oleh masyarakat terhadap suatu produk.

\section{Harga}

"Dalam teori ekonomi, harga (price), nilai (value), dan manfaat (utility) merupakan konsep yang saling berkaitan, manfaat adalah atribut sebuah item/barang yang mempunyai kemampuan untuk memuaskan keinginan, nilai adalah ukuran kuantitatif bobot sebuah produk yang dapat dipertukarkan dengan produk lain, harga adalah nilai yang disebutkan dalam bentuk mata uang seperti rupiah, dinar atau dolar, contohnya medium moneter lainnya sebagai nilai tukar"(Malau, 2016:125).

Adapun indikator dari variabel harga menurut Tandjung, (2004:78) sebagai berikut: a. Harga sesuai dengan yang disampaikan di brosur

Setiap usaha yang melakukan pemasaran dengan menyebarkan sebuah brosur kepada calon konsumen, maka isi dari brosur tersebut harus sesuai dengan keadaan usaha yang akan dibangun. Baik dari harga dari apa yang dijual, tempat beroperasi suatu usaha, serta produk apa sajakah yang dijual dalam suatu usaha tersebut.

b. Kesesuaian harga dengan kualitas produk

Menurut Kotler dan Keller (2009:23), penetapan harga itu sulit, karena berbagai produk mempunyai permintaan dan biaya yang saling terkait dan terpapar pada berbagai tingkat persaingan. Suatu perusahaan atau organisasi baik yang mengutamakan laba maupun tidak, pasti akan selalu berhubungan dengan penetapan harga yang harus sesuai dengan produk yang dihasilkan. Dimana sebelumnya lebih dulu perusahaan merumuskan mengenai penetapan harga yang sesuai dengan bauran produk serta keuntungan yang ingin dicapai. "Harga merupakan nilai tukar suatu barang atau jasa, dengan kata lain, itu merupakan produk yang dapat di tukar di pasar"(Malau, 2016:125).

c. Harga yang terjangkau

Menurut Kodu (2013), "harga adalah segala bentuk biaya moneter yang dikorbankan oleh konsumen untuk memperoleh dan memanfaatkan sejumlah kombinasi dari barang beserta pelayanan dari suatu produk, dimana dalam penetapan harga yang harus sesuai dengan bauran produk serta dapat dijangkau oleh konsumen atau pelanggan".

d. Kesesuaian harga dengan keinginan Perusahaan melakukan penetapan harga dengan berbagai cara, di perusahaan skala kecil, harga sering ditentukan oleh atasan, sedangkan di perusahaan skala besar, penetapan harga ditangani oleh manajer divisi dan manajer lini produk, bahkan manajer puncak menetapkan tujuan dan kebijakan menetapkan harga umum dan sering menyetujui harga yang 
diajukan oleh tingkat manajemen yang lebih rendah dan kesesuaian dengan keinginan agar dapat menarik minat konsumen atau pelanggan (Kotler dan keller, 2009:69).

Dari beberapa penjelasan indikator-indikator harga di atas, dan setelah disesuaikan dengan yang diteliti, maka peneliti hanya memakai indikator harga dalam penelitian ini yaitu: kesesuaian harga dengan kualitas produk, harga yang terjangkau, dan kesesuaian harga dengan keinginan. Peneliti tidak menggunakan indikator harga sesuai dengan yang disampaikan di brosur, karena semua usaha yang ada di wisata kuliner pantai Jempol, tidak menggunakan teknik pemasaran tersebut, dikarenakan pantai Jempol adalah tempat wisata dan berada dipusat keramaian, dan orangorang datang berbelanja sambil menikmati pemandangan pantai.

\section{Tempat}

Tempat atau lokasi, kedudukan secara fisik yang mempunyai fungsi strategis karena dapat ikut menentukan tercapainya tujuan badan usaha (Sriyadi, 1991:60). Lokasi diartikan sebagai saluran distribusi untuk produk industri manufaktur sedangkan lokasi diartikan sebagai tempat pelayanan jasa untuk produk industri jasa (Hariyati, 2005:55)

Lokasi yang dipilih haruslah mampu membuat usahanya mengalami pertumbuhan ekonomi sehingga dapat bertahan lama. Jika nilai lokasi memburuk akibat perubahan lingkungan yang dapat terjadi setiap waktu, kemungkinan usaha tersebut harus dipindahkan atau ditutup.

Menurut Tjiptono, (1997:96) terdapat beberapa indikator dari variabel tempat tersebut. Adapun indikator dari variabel tempat sebagai berikut:

\section{Lokasi strategis}

Lokasi yang strategis berarti berhubungan dengan dimana dan bagaimana perusahaan harus bermarkas dan melakukan operasi, dalam hal ini ada tiga jenis interaksi yang memengaruhi lokasi, yaitu:

a. Konsumen mendatangi pemberi barang atau jasa (perusahaan atau tempat usaha)

Apabila keadaanya seperti ini maka lokasi menjadi sangat penting, perusahaan sebaiknya memilih tempat dekat dengan konsumen sehingga mudah dijangkau, dengan kata lain harus strategis.

b. Pembeli barang atau jasa mendatangi konsumen

Dalam hal ini lokasi tidak terlalu penting tetapi yang harus diperhatikan adalah penyampaian jasa harus tetap berkualitas.

c. Pembeli barang atau jasa dan konsumen tidak bertemu secara langsung, konsumen berinteraksi melalui sarana tertentu seperti telepon atau sosmed. Dalam hal ini lokasi menjadi sangat tidak penting selama komunikasi antara kedua belah pihak dapat terlaksana.

2. Mudah dijangkau konsumen

Dalam memilih lokasi untuk menjalankan suatu usaha, para pengusaha/pelaku usaha perlu mempertimbangkan beberapa faktor, diantaranya:

a. Akses yaitu kemudahan untuk menjangkau,

b. Visibilitas yaitu kemudahan untuk dilihat,

c. Lalu lintas, ada 2 hal yang perlu diperhatikan yaitu banyaknya orang yang lalu lalang bisa memberikan peluang yang besar tejadinya impuls buying (pembelian secara tiba-tiba) dan keramaian serta kemacetan bisa menjadi hambatan,

d. Lingkungan yaitu daerah sekitar yang mendukung barang atau jasa yang ditawarkan,

e. Persaingan yaitu lokasi dengan pesaing sejenis.

3. Suasana yang aman,

Setiap pemilihan lokasi untuk menjalankan suatu usaha atau bisnis, para pengusaha/ pelaku usaha perlu melihat berbagai faktor seperti keamanan disekitar lokasi usaha seperti tempat parkiran yang aman agar pelanggan nyaman berada dilokasi tersebut karena terjamin keamanan kendaraannya.

\section{Keputusan pembelian}

Menurut yang dikatakan Tampi, (2016) mendefinisikan keputusan pembelian adalah pemilihan dari dua atau lebih alternatif pilihan keputusan pembelian, artinya bahwa seseorang dapat membuat keputusan, harus tersedia beberapa alternatif pilihan. Keputusan pembelian merupakan sikap dan ketertarikan seseorang untuk 
membeli atau menggunakan suatu produk baik berupa barang atau jasa yang telah diyakini akan memuaskan dirinya dan kesediaan menanggung resiko yang mungkin ditimbulkanya. Keputusan pembelian yang diambil oleh pembeli sebenarnya merupakan kumpulan dari sejumlah keputusan yang terorganisir (Kodu, 2013). Sedangkan indikator untuk mengukur keputusan pembelian yang diambil oleh konsumen, menurut Hasan (2014: 180) adalah:

1. Pengenalan masalah

Masalah merupakan hasil dari perbedaan antara keadaan yang diinginkan konsumen dan keadaan yang sebenarnya dihadapai, dan konsumen termotivasi untuk mengatasi perbedaan tersebut dan karena itu mereka memulai proses pembelian. Dimana masalah yang terjadi diwisata kuliner pantai Jempol sehingga konsumen memutuskan untuk membeli yaitu, wisata kuliner pantai Jempol berada di pusat keramaian, tempat wisata pantai, dan memiliki produk dan kuliner yang berkualitas, serta memiliki harga yng terjangkau.

2. Mencari informasi

Tahap ini merangsang konsumen untuk mencari informasi lebih banyak mengenai suatu barang atau jasa yang ingin dibelinya. Konsumen hanya meningkatkan perhatian atau aktif mencari informasi mengenai suatu produk. Dalam hal ini konsumen mulai mengetahui akan merek dan kualitas akan produk tersebut.

3. Evaluasi alternatif

Tahap ini merupakan proses keputusan pembelian ketika konsumen menggunakan informasi untuk mengevaluasi merek altenatif dalam menentukan pilihan. Disini konsumen akan memiliki beberapa pilihan mengenai produk yang akan dibelinya. Dari beberapa pilihan tersebut konsumen akan mengevaluasi mana yang menjadi pilihan terbaik.

4. Keputusan pembelian

Setelah konsumen mengevaluasi beberapa alternatif yang ada, konsumen akan membuat keputusan pembelian. Terkadang waktu yang dibutuhkan antara membuat keputusan pembelian dengan menciptakan pembelian yang sebenarnya tidak sama dikarenakan adanya hal-hal lain yang perlu dipertimbangkan.

5. Evaluasi pembelian

Setelah membeli produk tersebut, konsumen akan melakukan evaluasi apakah produk tersebut sesuai dengan harapannya. Dalam hal ini, terjadi kepuasan dan ketidakpuasan konsumen. Konsumen akan puas jika produk tersebut sesuai dengan harapannya dan selanjutnya akan meningkatkan permintaan akan merek produk tersebut pada masa depan atau pembelian selanjutnya. Sebaliknya, konsumen akan merasa tidak puas jika produk tersebut tidak sesuai dengan harapannya dan hal ini akan menurunkan permintaan konsumen pada pembelian selanjutnya.

\section{Kerangka Pemikiran}

Kerangka pemikiran menggambarkan hubungan dari variabel independen, dalam hal ini adalah produk $\left(\mathrm{X}_{1}\right)$, harga $\left(\mathrm{X}_{2}\right)$, dan tempat $\left(\mathrm{X}_{3}\right)$ terhadap variabel dependen yaitu keputusan pembelian (Y) yang dilakukan oleh konsumen.

Kerangka Pemikiran Teoritis

\section{Variabel Independent Variabel Dependent}

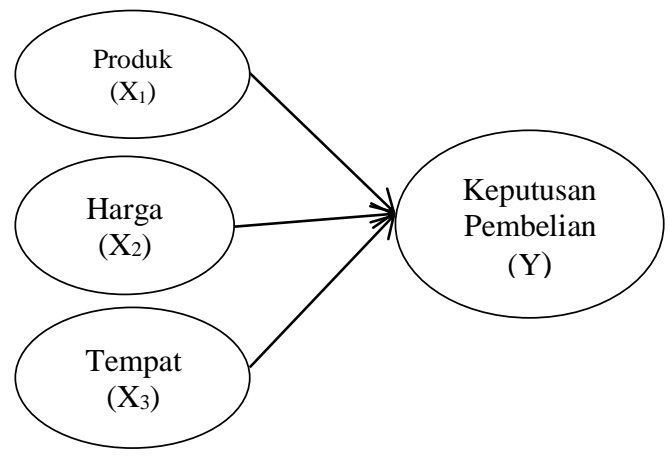

Sumber: Achidah dkk, (2016).

\section{MATODOLOGI PENELITIAN}

Metode Penelitian

Penelitian ini menggunakan metode analisis kuantitatif asosiatif. Kuantitatif merupakan metode analisa data yang memerlukan perhitungan statistik dan matematis yang digunakan untuk menganalisis data yang dinyatakan dalam bentuk angka-angka dimana data tersebut diperoleh dari jawaban kuesioner menggunakan program SPSS. Sedangkan penelitian asosiatif merupakan penelitian yang 
bertujuan untuk mengetahui pengaruh antara dua variabel atau lebih yaitu melihat pengaruh kualitas produk, harga dan tempat terhadap keputusan pembelian konsumen (Tampi, 2016).

\section{Populasi dan Sampel}

Populasi adalah wilayah generalisasi yang terdiri atas objek/subjek yang mempunyai kualitas dan karakteristik atau sifat yang dimiliki oleh subjek tertentu yang ditetapkan oleh peneliti untuk dipelajari dan kemudian ditarik kesimpulan (Anshori dan Iswati 2006:92). Populasi dalam penelitian ini adalah seluruh konsumen yang pernah datang dan membeli diwarung-warung yang ada di wisata kuliner Pantai Jempol.

Menurut Anshori dan Iswati, (2006:94) sampel adalah bagian dari jumlah dan karasteristrik yang dimiliki oleh populasi. Sampel dari penelitian ini adalah konsumen yang datang membeli dan memiliki kriteria sebagai berikut:

a. Warung dekat dari Jempol (jembatan polak).

b. Warung yang memiliki pendapatan minimal Rp.500.000/hari.

c. Konsumen yang berumur 17 tahun ke atas.

Penentuan jumlah sampel dengan jumlah populasi $(\mathrm{N})$ tidak dapat ditentukan (tak terhingga jumlahnya), maka penentuan jumlah sampel akan menggunakan rumus sebagai berikut (Widiyanto, 2008:59) :

$$
\mathbf{n}=\frac{\mathbf{Z}^{2}}{\mathbf{4}(\text { Moe })^{2}}
$$

Keterangan :

$$
\begin{array}{rlr}
\mathrm{n}= & \text { Ukuran sampel } \\
\mathrm{Z}= & \text { Standar } & \text { skor pada } \\
& \text { tingkat } & \text { signifikansi } \\
& \text { tertentu } & \text { (derajat } \\
& \text { keyakinan } & \text { ditentukan } \\
& 95 \% \text { ) maka } \mathrm{Z}=1.96 \\
= & \text { Margin of error, } \\
& \text { tingkat } \text { kesalahan } \\
& \text { maksimum adalah } \\
& 5 \% .
\end{array}
$$

Berdasarkan rumus di atas, maka diperoleh perhitungan sebagai berikut:

$$
\begin{aligned}
\mathbf{n} & =\frac{(1,96)^{2}}{4(5 \%)^{2}} \\
& =\frac{3,8416}{4(0,05)^{2}} \\
& =\frac{3,8416}{0,04} \\
\mathbf{n} & =96,04=97
\end{aligned}
$$

Dari hasil perhitungan rumus di atas, maka diperoleh jumlah sampel yang diteliti adalah sebesar 97, atau dilakukan pembulatan menjadi 100 responden yang dapat mewakili konsumen yang membeli di wisata kuliner Pantai Jempol.

\section{Pengumpulan Data}

Data yang diperoleh dalam penelitian ini adalah data primer. Data primer adalah sumber data yang pertama kali di catat dan dikumpulkan oleh peneliti (Sanusi, 2011:104). Data ini dapat berupa opini subyek (orang) secara individual atau kelompok. Data ini diperlukan untuk mengetahui tanggapan konsumen terhadap pembelian di wisata kuliner Pantai Jempol yang dapat dilihat dari produk, harga dan tempat. Untuk mendapatkan data tersebut, akan dibagikan kuesioner kepada para responden.

\section{ANALISIS DATA}

\section{Uji Validitas dan Uji Reliabilitas}

\section{Uji Validitas}

Suatu pengujian yang digunakan untuk mengukur sah atau tidaknya suatu kuesioner (Anshori dan Iswati, 2006:83). Suatu kuesioner dikatakan valid jika pertanyaan pada kuesioner mampu untuk mengungkapkan sesuatu yang akan diukur. Kriteria penilaian uji validitas adalah :

- Apabila $r$ hitung > r tabel, maka kuesioner tersebut valid

- Apabila $\mathrm{r}$ hitung < r tabel, maka dapat dikatakan item kuesioner tidak valid.

Uji Validitas

\begin{tabular}{|c|c|c|c|c|}
\hline Variabel & $\begin{array}{c}\text { Item } \\
\text { Pertanyaan }\end{array}$ & R hitung & R table & Keterangan \\
\hline $\begin{array}{c}\text { Produk } \\
\text { (X1) }\end{array}$ & P1 & 0.790 & 0.361 & Valid \\
& P3 & 0.803 & 0.361 & Valid \\
& P4 & 0.763 & 0.361 & Valid \\
Harga & H1 & 0.589 & 0.361 & Valid \\
\hline X2) & H2 & 0.740 & 0.361 & Valid \\
Tempat & T1 & 0.763 & 0.361 & Valid \\
(X3) & T2 & 0.707 & 0.361 & Valid \\
\hline \multirow{2}{*}{$\begin{array}{c}\text { Keputusan } \\
\text { pembelian }\end{array}$} & T3 & 0.690 & 0.361 & Valid \\
KP) & KP3 & 0.731 & 0.361 & Valid \\
& KP4 & 0.441 & 0.361 & Valid \\
\hline Ku5 & 0.699 & 0.361 & Valid \\
\hline
\end{tabular}

Sumber: Data Output SPSS 16.0, diolah tahun 2018 


\section{Uji Reliabilitas}

Uji reliabilitas merupakan pengujian yang menunjukan sejauh mana stabilitas dan kekonsistenan dari alat ukur yang digunakan. Menurut Anshori dan Iswati, (2006:75) instrumen yang reliabel adalah instrumen yang bila digunakan beberapa kali untuk mengukur obyek yang sama, akan menghasilkan data (ukuran) yang tetap sama. Uji reliabilitas penelitian ini menggunakan program SPSS. Kuesioner dikatakan reliabel apabila hasil uji statistik Alpha $\alpha$ $>0,60$.

\section{Uji Reliabilitas}

\begin{tabular}{|l|c|c|}
\hline \multicolumn{1}{|c|}{ Variabel } & $\begin{array}{c}\text { Cronbach } \\
\text { Alpha }\end{array}$ & Keterangan \\
\hline Produk & 0.795 & Reliable \\
Harga & 0.792 & Reliable \\
$\begin{array}{l}\text { Tempat } \\
\text { Keputusan } \\
\text { pembelian }\end{array}$ & 0.790 & $\begin{array}{l}\text { Reliable } \\
\text { Reliable }\end{array}$ \\
\hline
\end{tabular}
2018

Sumber: Data Output SPSS 16.0, diolah tahun

\section{Uji Asumsi Klasik}

Uji asumsi klasik bertujuan untuk mengetahui kondisi data yang dipergunakan dalam penelitian. Hal tersebut dilakukan agar diperoleh model analisis yang tepat (Sunyoto, 2011:134). Penelitian ini terdiri dari uji normalitas, uji multikolinearitas, uji heteroskedastitas, dan uji linearitas.

a. Uji Normalitas

Uji normalitas bertujuan untuk mengetahui normal atau tidaknya suatu distribusi data. Uji normalitas pada penelitian ini menggunakan bantuan program SPSS Statisic 16 for windows dengan statistik One sample kolmogrov smirnov test. Pengukuran yang digunakan adalah membandingkan nilai Asymp. Sig (2-Tailed) dengan nilai yang ditentukan sebesar 5\%. Apabila nilai Asymp. Sig (2-Tailed) lebih besar dari 0,05 maka dapat disimpulkan bahwa data tersebut berdistribusi normal. Hasil uji normalitas adalah sebagai berikut:

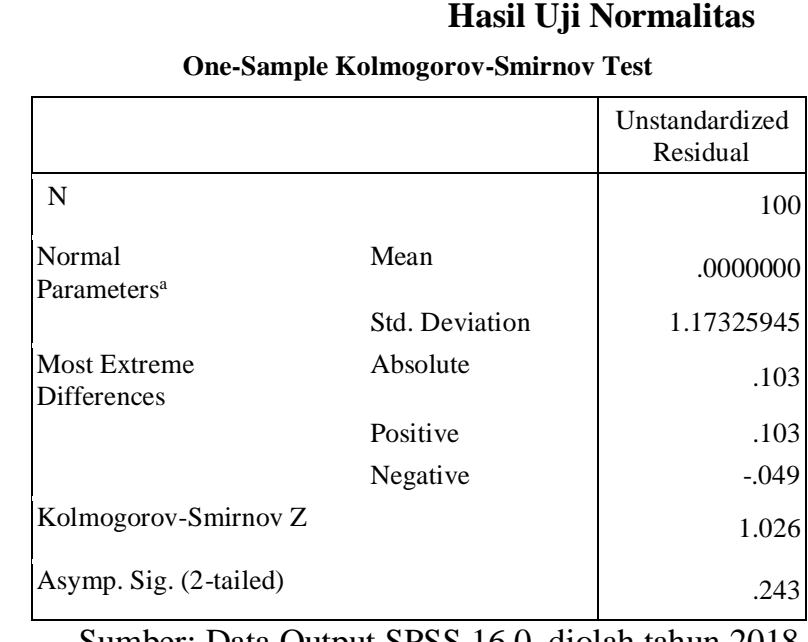

Sumber: Data Output SPSS 16.0, diolah tahun 2018

Berdasarkan tabel hasil uji normalitas di atas diperoleh Asymp. Sig (2-tailed) sebesar 0,243 yang berarti lebih besar dari 0,05, maka dapat disimpulkan bahwa data dalam penelitian ini mempunyai distribusi normal.

b. Uji Multikolinearitas

Uji multikolinearitas bertujuan untuk mengetahui apakah terdapat gejala korelasi antar variabel independent lainnya. Model regresi yang baik seharusnya tidak terjadi korelasi diantara variabel bebas. Pemeriksaan untuk mendeteksi multikolinieritas dilakukan VIF (Variance Inflation Factor) yang dihitung dengan menggunakan SPSS Statisic 16 for windows. Hasil uji multikolinieritas disajikan dalam tabel berikut:

Hasil Uji Multikolinearitas

\begin{tabular}{|l|c|c|l|}
\hline Variabel & Tolerance & VIF & Keterangan \\
\hline Produk & 0.906 & 1.104 & $\begin{array}{l}\text { Tidak terjadi } \\
\text { multikolinearitas }\end{array}$ \\
\hline Harga & 0.847 & 1.180 & $\begin{array}{l}\text { Tidak terjadi } \\
\text { multikolinearitas }\end{array}$ \\
\hline Tempat & 0.774 & 1.292 & $\begin{array}{l}\text { Tidak terjadi } \\
\text { multikolinearitas }\end{array}$ \\
\hline
\end{tabular}

Sumber: Data Output SPSS 16.0, diolah tahun 2018 Berdasarkan tabel di atas menunjukan bahwa semua nilai tolerance dari masing-masing variabel lebih besar dari 0,1 dan VIF lebih kecil dari 10 maka disimpulkan bahwa dari seluruh variabel bebas dalam penelitian ini tidak terjadi multikolinearitas.

c. Uji Heteroskedastisitas

Uji ini menunjukkan terjadi ketidaksamaan varian dari residual, dari satu pengamatan ke pengamatan yang 
lain. Pendeteksian ada atau tidaknya heteroskedastisitas dilakukan dengan menggunakan scatterplot antara nilai variabel bebas (ZPRED) pada data sumbu $X$ dan variabel terikat (SRESID) pada sumbu Y. Jika scatterplot menghasilkan titik-titik yang tidak berbentuk pola-pola tertentu dan titiktitik menyebar di atas dan di bawa angka nol pada sumbu Y, maka disimpilkan tidak terjadi heteroskedastisitas pada model regresi. Berikut gambar scatterplot yang dihasilkan dari model regresi:

\section{Hasil Uji Heteroskedastisitas}

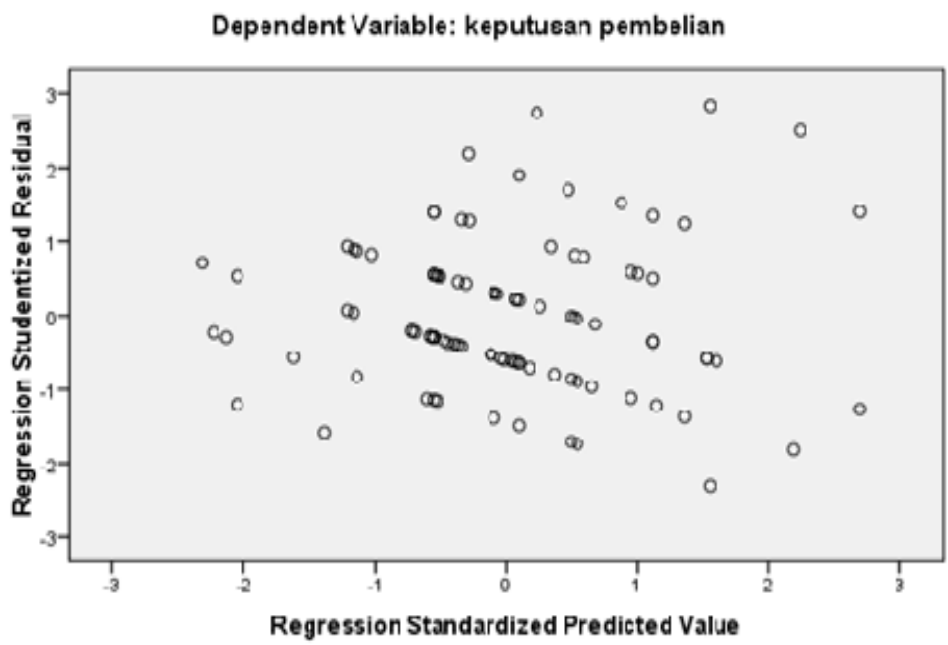

Sumber: Data Output SPSS 16.0, diolah tahun 2018

Gambar di atas menunjukkan titik-titik tidak membentuk pola tertentu dan titik-titik menyebar di atas dan di bawa angka nol pada sumbu Y, sehingga dapat disimpulkan tidak terjadi heteroskedastisitas dalam model regresi, dengan demikian asumsi non heteroskedastisitas terpenuhi.

d. Uji Linearitas

Uji linearitas bertujuan untuk mengetahui apakah dua variabel mempunyai hubungan yang linear atau tidak secara signifikan, uji ini biasanya digunakan sebagai prasyarat dalam analisis korelasi atau regresi linear. Pengujian pada SPSS dengan melihat nilai linearity pada taraf signifikan 0,05 . Dua variabel dikatakan mempunyai hubungan linear bila signifikan (linearity) lebih kecil dari 0,05.
Hasil Uji Linearitas Produk dan Keputusan Pembelian ANOVA Table

\begin{tabular}{|c|c|c|c|c|c|c|c|}
\hline & & & $\begin{array}{l}\text { Sum of } \\
\text { Squares }\end{array}$ & df & $\begin{array}{l}\text { Mean } \\
\text { Square }\end{array}$ & $\mathrm{F}$ & Sig. \\
\hline \multirow{5}{*}{$\begin{array}{l}\text { Keputusan } \\
\text { Pembelian } \\
* \text { Produk }\end{array}$} & $\begin{array}{l}\text { Bet } \\
\text { wee }\end{array}$ & $\begin{array}{l}\text { (Combin } \\
\text { ed) }\end{array}$ & 8.394 & 7 & 1.199 & .654 & .710 \\
\hline & & Linearity & 2.385 & 1 & 2.385 & 1.302 & .257 \\
\hline & ups & $\begin{array}{l}\text { Deviatio } \\
\mathrm{n} \text { from } \\
\text { Linearity }\end{array}$ & 6.009 & 6 & 1.001 & .546 & .772 \\
\hline & & $\begin{array}{l}\text { Within } \\
\text { Groups }\end{array}$ & 168.606 & 92 & 1.833 & & \\
\hline & & Total & 177.000 & 99 & & & \\
\hline
\end{tabular}

Sumber: Data Output SPSS 16.0, diolah tahun 2018 Berdasarkan tabel di atas diketahui nilai signifikan Linearity antara produk dan keputusan pembelian yaitu 0.257 lebih besar dari 0.05 yang artinya bahwa secara statistik produk tidak berpengaruh secara linear terhadap keputusan pembelian.

\section{Hasil Uji Linearitas Harga dan Keputusan Pembelian} ANOVA Table

\begin{tabular}{|c|c|c|c|c|c|c|c|}
\hline & & & $\begin{array}{l}\text { Sum of } \\
\text { Squares }\end{array}$ & Df & $\begin{array}{l}\text { Mean } \\
\text { Square }\end{array}$ & $\mathrm{F}$ & Sig. \\
\hline \multirow{5}{*}{$\begin{array}{l}\text { Keputusan } \\
\text { Pembelian } \\
\text { * Harga }\end{array}$} & \multirow{3}{*}{$\begin{array}{l}\text { Between } \\
\text { Groups }\end{array}$} & (Combin & 36.123 & 6 & 6.021 & 3.974 & .001 \\
\hline & & Linearity & 32.360 & 1 & 32.360 & 21.363 & .000 \\
\hline & & $\begin{array}{l}\text { Deviatio } \\
\mathrm{n} \text { from } \\
\text { Linearity }\end{array}$ & 3.763 & 5 & .753 & .497 & .778 \\
\hline & \multicolumn{2}{|c|}{ Within Groups } & 140.877 & 93 & 1.515 & & \\
\hline & \multicolumn{2}{|l|}{ Total } & 177.000 & 99 & & & \\
\hline
\end{tabular}

Sumber: Data Output SPSS 16.0, diolah tahun 2018 Berdasarkan tabel di atas diketahui nilai signifikan Linearity antara harga dan keputusan pembelian yaitu 0.000 lebih besar dari 0.05 yang artinya bahwa secara statistik harga berpengaruh secara linear terhadap keputusan pembelian. 


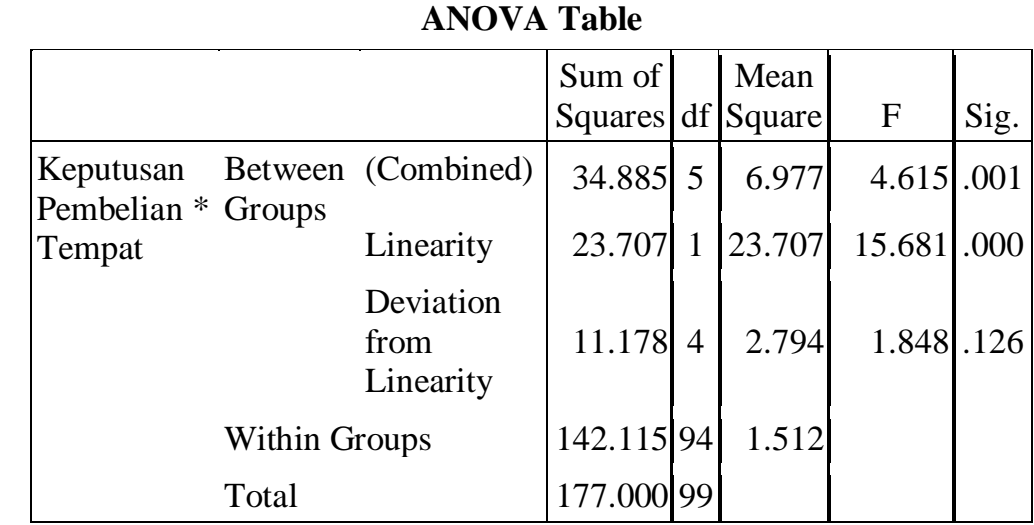

Sumber: Data Output SPSS 16.0, diolah tahun 2018 Berdasarkan tabel di atas diketahui nilai signifikan Linearity antara tempat dan keputusan pembelian yaitu 0.000 lebih besar dari 0.05 yang artinya bahwa secara statistik tempat berpengaruh secara linear terhadap keputusan pembelian.

\section{Uji Hipotesis}

a. Analisis Regresi Linear Berganda Persamaan yang digunakan dalam penelitian ini adalah sebagai berikut:

$$
\mathbf{b}_{3} \mathbf{X}_{3}+\mathbf{e}
$$

$$
\mathbf{Y}=\mathbf{a}+\mathbf{b}_{1} \mathbf{X}_{1}+\mathbf{b}_{2} \mathbf{X}_{2}+
$$

Hasil Analisis Regresi Liner

\begin{tabular}{|c|c|c|c|c|c|c|}
\hline & & \multicolumn{2}{|c|}{$\begin{array}{l}\text { Unstandardized } \\
\text { Coefficients }\end{array}$} & \multirow{2}{*}{$\begin{array}{c}\begin{array}{c}\text { Standardized } \\
\text { Coefficients }\end{array} \\
\text { Beta }\end{array}$} & \multirow[b]{2}{*}{$\mathrm{T}$} & \multirow[b]{2}{*}{ Sig. } \\
\hline \multicolumn{2}{|c|}{ Model } & B & Std. Error & & & \\
\hline 1 & (Constant) & 9.122 & 1.449 & & 6.297 & .000 \\
\hline & Produk & .016 & .086 & .018 & .190 & .850 \\
\hline & Harga & .395 & .114 & .337 & 3.462 & .001 \\
\hline & Tempat & .275 & .122 & .230 & 2.255 & .026 \\
\hline
\end{tabular}

Coefficients $^{\mathrm{a}}$

Dependent Variable: Keputusan Pembelian Sumber: Data Output SPSS

16.0, diolah tahun 2018

Berdasarkan tabel di atas maka

persamaan regresinya sebagai berikut:

$$
\begin{aligned}
& Y=9.122+0.016 X_{1}+ \\
& 0.395 X_{2}+0.275 X_{3}+e
\end{aligned}
$$

a) Nilai konstanta sebesar 9.122 menunjukkan bahwa ketika nilai variabel independent yaitu variabel produk, harga dan tempat diasumsikan diabaikan maka nilai keputusan pembelian sebesar 9.122.

b) Nilai koefisien produk yaitu 0,016 menunjukkan apabila nilai produk mengalami kenaikan satu satuan sementara variabel independent lainnya diasumsikan tetap maka nilai keputusan pembelian akan meningkat sebesar 0,016.

c) Nilai koefisien harga sebesar 0,395 berarti apabila nilai harga mengalami peningkatan sebesar satu satuan dan variabel independent lainnya diasumsikan tetap maka nilai keputusan pembelian akan mengalami kenaikan sebesar 0,395

d) Nilai koefisien tempat yaitu sebesar 0,275 hal ini berarti apabila nilai tempat mengalami kenaikan satu satuan sedangkan variabel independen lain diasumsikan tetap maka nilai variabel keputusan pembelian akan meningkat sebesar 0,275.

b. Uji Parsial (uji t)

Uji $t$ digunakan untuk mengetahui pengaruh variabel independent (produk, harga, dan tempat) secara individu terhadap variabel dependent (keputusan pembelian). Nilai $\mathrm{t}$ tabel dalam penelitian ini adalah 1.984 (dengan melihat $\mathrm{t}$ tabel pada tingkat signifikan 0.05).

\begin{tabular}{|cc|c|c|}
\multicolumn{4}{c|}{ Hasil Parsial (uji t) } \\
\multicolumn{1}{|c|}{ Model } & $\mathrm{T}$ & Sig. \\
\hline 1 & (Constant) & 6.297 & .000 \\
& Produk & .190 & .850 \\
& Harga & 3.462 & .001 \\
& Tempat & 2.255 & .026 \\
\hline
\end{tabular}

Sumber: Data Output SPSS 16.0, diolah tahun 2018

a) Variabel Produk

Hasil output tabel di atas menunjukan bahwa nilai $\mathrm{t}$ hitung produk $\left(\mathrm{X}_{1}\right)$ sebesar 0,190 lebih kecil dari t tabel 1,984 dengan nilai signifikansi 0,850 lebih besar dari 0,05 maka hipotesis pertama ditolak, yang berarti harga tidak berpengaruh signifikan terhadap keputusan pembelian.

b) Variabel Harga

Dilihat dari tabel di atas menunjukan bahwa nilai $\mathrm{t}$ hitung harga $\left(\mathrm{X}_{2}\right)$ sebesar 3.462 lebih besar dari t tabel 1,984 dengan nilai signifikansi sebesar 0,001 lebih kecil dari 0,05 maka hipotesis kedua diterima, yang dimaksud harga berpengaruh signifikan terhadap keputusan pembelian.

c) Variabel Tempat

Dilihat dari tabel di atas menunjukan bahwa nilai $\mathrm{t}$ hitung tempat $\left(\mathrm{X}_{3}\right)$ sebesar 2.255 lebih besar dari t tabel 1.984 dengan nilai signifikansi 
sebesar 0,026 lebih kecil dari 0,05 maka hipotesis ketiga diterima, yang dimaksud tempat berpengaruh signifikan terhadap keputusan pembelian.

c. Hasil Uji Simultan (uji f)

Uji f dilakukan untuk melihat pengaruh variabel-variabel independent secara keseluruhan terhadap variabel dependent. Pengujian ini dilakukan dengan membandingkan nilai f hitung dengan $f$ tabel.

Hasil Simultan (uji f)

ANOVA $^{b}$

\begin{tabular}{|cl|c|c|c|c|c|}
\hline \multirow{2}{*}{ Model } & $\begin{array}{c}\text { Sum of } \\
\text { Squares }\end{array}$ & Df & $\begin{array}{c}\text { Mean } \\
\text { Square }\end{array}$ & F & Sig. \\
\hline 1 & Regression & 40.723 & 3 & 13.574 & 9.562 & $.000^{\mathrm{a}}$ \\
& Residual & 136.277 & 96 & 1.420 & & \\
& Total & 177.000 & 99 & & & \\
\hline
\end{tabular}

a. Predictors: (Constant), produk, harga, te

b. Dependent Variable: keputusan pembelian

Sumber: Data Output SPSS 16.0, diolah tahun 2018 Uji F dilakukan untuk mengetahui pengaruh variabel-variabel independent terhadap variabel dependent. Berdasarkan output pada tabel di atas uji $\mathrm{F}$ di atas, diketahui nilai $\mathrm{F}$ hitung 9,562 lebih besar dari $\mathrm{F}$ tabel 2,70 dengan nilai signifikansi 0,000 lebih kecil dari 0,05 maka dapat disimpulkan bahwa terdapat pengaruh signifikan secara bersama-sama antara produk $\left(\mathrm{X}_{1}\right)$, harga $\left(\mathrm{X}_{2}\right)$, dan tempat $\left(\mathrm{X}_{3}\right)$ terhdap keputusan pembelian(Y).

d. Hasil Uji Koefisien Determinasi (R Square).

Analisis ini untuk mengetahui seberapa besar kemampuan variabel independen menjelaskan variabel dependen. Dari uji analisis koefisien determinasi diperoleh hasil sebagai berikut:
Sumber: Data Output SPSS 16.0, diolah tahun 2018 Besarnya nilai koefisien determinasi ditunjukkan pada tabel di atas dengan nilai $\mathrm{R}$ square adalah 0,230. Hasil ini menunjukan bahwa pengaruh produk, harga, dan tempat terhadap keputusan pembelian sebesar $23 \%$ dan sisanya $77 \%$ dipengaruhi oleh faktorfaktor lain diluar penelitian ini seperti promosi.

e. Koefisien Determinasi Yang Disesuaikan (Adjusted R Square)

Adjusted $\mathrm{R}$ square adalah nilai $\mathrm{R}$ Square yang telah disesuaikan, nilai ini selalu lebih kecil dari R Square. Pada penjelasan di atas terlihat bahwa nilai Adjusted R Square sebesar 0.206. Nilai Adjusted R Square dapat naik atau turun berdasarkan signifikasi variabel independent. Adjusted R Square dapat bernilai negatif, sehingga jika nilainya negatif, maka nilai tersebut dianggap 0 atau variabel bebas sama sekali tidak mampu menjelaskan varian dari variabel terikat.

\section{PEMBAHASAN}

\section{Pengaruh Produk Terhadap Keputusan Pembelian}

Produk merupakan suatu barang nyata yang dapat terlihat atau berwujud dan dapat dipegang yang dirancang serta diproduksi untuk memuaskan keinginan atau kebutuhan konsumen. Dalam sebuah usaha atau perusahaan, harus memiliki kualitas produk yang baik agar dapat bersaing dengan perusahaan atau pengusaha lainnya. Menurut (Kotler dan Keller, 2009:4), "produk adalah segala sesuatu yang dapat ditawarkan kepada pasar untuk memuaskan suatu keinginan atau kebutuhan, termasuk barang fisik, jasa, pengalaman, acara, orang, tempat, properti, informasi, dan ide".

Dengan hasil pengujian yang disajikan pada tabel-tabel di atas yang memberikan kesimpulan bahwa variabel produk tidak berpengaruh signifikan terhadap keputusan pembelian di wisata kuliner pantai Jempol. Hal ini tidak mendukung hipotesis pertama bahwa variabel produk berpengaruh signifikan terhadap keputusan pembelian di wisata kuliner pantai Jempol. Hasil penelitian ini bertolak belakang dengan penelitian yang dilakukan oleh Hariadi (2012) yang menyatakan bahwa variabel produk berpengaruh signifikan terhadap keputusan pembelian. Kesimpulan hasil penelitian ini 
adalah variabel produk secara parsial tidak berpengaruh signifikan terhadap keputusan pembelian.

Berdasarkan fenomena yang terjadi dalam penelitian ini disebabkan karena konsumen tidak terlalu mempertimbangkan produk yang dijual di warung-warung yang ada di wisata kuliner pantai Jempol. Dikarenakan dalam penelitian ini hampir semua jenis produk yang disediakan oleh warung relatif sama antara warung satu dan warung lainnya, sehingga konsumen yang datang hanya akan berpatokan pada tempat yang nyaman dan pemandangan pantainya, serta harga yang disediakan disetiap warung relatif dapat dijangkau oleh semua kalangan masyarakat dan sebagian warung juga menyediakan beberapa strategi untuk menarik minat konsumen seperti menyediakan musik dan tempat karaoke. Sehingga dalam fenomena itu, konsumen tidak terlalu melihat dari segi produknya agar dapat memutuskan untuk membeli disetiap warung-warung yang ada di wisata kuliner pantai Jempol.

\section{Pengaruh Harga Terhadap Keputusan Pembelian}

Hasil pengujian yang disajikan pada tabel-tabel di atas memberikan kesimpulan bahwa variabel harga pada wisata kuliner pantai Jempol yang dinilai dari persepsi responden dapat memberikan pengaruh terhadap keputusan pembelian konsumen. Hasil ini mendukung hipotesis kedua bahwa variabel harga berpengaruh signifikan terhadap keputusan pembelian di wisataa kuliner pantai Jempol.

Hipotesis yang diajukan atas dasar ini, dapat diketahui bahwa harga yang diukur dengan harga produk yang ditawarkan oleh setiap warung yang ada di wisata kuliner pantai Jempol terjangkau, harga produk yang ditawarkan sesuai dengan kualitas dan keinginan konsumen akan produk, sehingga harga dapat memengaruhi keputusan pembelian konsumen. Hasil ini sejalan dengan penelitian yang dilakukan oleh Achidah, dkk (2016) yang menyatakan bahwa harga memiliki pengaruh positif yang signifikan terhadap keputusan pembelian konsumen.

Berdasarkan fenomena yang terjadi dalam penelitian ini, bahwa harga berpengaruh signifikan terhadap keputusan membeli konsumen di wisata kuliner pantai Jempol. Salah satu fenomenanya, dimana harga yang disediakan oleh warung terhadap produknya sangat terjangkau oleh semua kalangan dibandingkan dengan tempat kuliner lain yang ada di Sumbawa. Terlebih juga karena wisata kuliner pantai Jempol, konsumen dapat langsung menikmati pemandangan pantai, yang sebenarnya pemandangan pantainya dapat memiliki nilai tambah terhadap patokan harga dari setiap produk atau makanan yang dijual di warungwarung. Akan tetapi harga produk atau makanan yang ada di wisata kuliner pantai Jempol tetap setara dengan warung-warung biasa yang tidak memiliki pemandangan atau keunikan lainnya.

Harga yang disediakan di wisata kuliner pantai Jempol sangantlah terjangkau dibandingkan dengan warung makan ternama yang ada di Sumbawa. Dimana makanan atau produk yang tersedia relatif sama dengan makanan atau produk yang tersedia di warung-warung yang ada di wisata kuliner pantai Jempol. Dan yang membedakan biasanya dari cita rasa dan cara penyajian makanan atau produknya, sehingga harga makanan atau produk yang ada di restoran atau warung makan ternama yang ada di Sumbawa relatif mahal dan tidak dapat dijangkau oleh kalangan menengah kebawah.

\section{Pengaruh Tempat Terhadap Keputusan Pembelian}

Faktor ketiga yang memengaruhi keputusan pembelian adalah tempat. Dari hasil pengujian yang disajikan pada tabeltabel di atas yang memberikan kesimpulan bahwa variabel tempat berpengaruh signifikan terhadap keputusan pembelian. Hasil ini mendukung hipotesis ketiga bahwa variabel tempat berpengaruh signifikan terhadap keputusan pembelian konsumen di wisata kuliner pantai Jempol.

Menurut Sriyadi (1991:60) mengatakan bahwa tempat atau lokasi merupakan kedudukan secara fisik yang mempunyai fungsi strategis karena dapat ikut menentukan tercapainya tujuan badan usaha. Lokasi yang dipilih haruslah mampu membuat usaha mengalami pertumbuhan ekonomi sehingga dapat bertahan lama. Dalam penelitian ini tempat atau lokasi wisata kuliner pantai Jempol sangat strategis karena berada dipusat keramaian, maka dari itulah tempat memiliki pengaruh terhadap keputusan pembelian konsumen di wisata kuliner pantai Jempol. Hasil penelitian ini sejalan atau relevan dengan penelitian sebelumnya yang dilakukan oleh Kurniawan (2013) yang menyatakan bahwa tempat berpengaruh signifikan terhadap keputusan pembelian konsumen.

Berdasarkan fenomena yang terjadi dalam penelitian ini bahwa tempat berpengaruh signifikan terhadap keputusan 
membeli konsumen di wisata kuliner pantai Jempol. Dimana tempat wisata kuliner pantai Jempol berada di labuhan Sumbawa atau berada dipinggiran pantai. Maka konsumen yang datang ke tempat kuliner tersebut akan dimanjakan dengan keindahan pemandangan pantai diwaktu sore hari dan angin pantai diwaktu malam hari. Tempat wisata kuliner pantai Jempol juga sudah menjadi tempat pusat keramaian kota dan satu-satunya tempat kuliner yang ada di Sumbawa, dimana konsumen dapat langsung menikmati keindahan pantai.

Di wisata kuliner pantai Jempol adalah suatu tempat yang strategis dimana tempat wisata kuliner pantai Jempol sudah menjadi pusat keramaian kota yang ada di Sumbawa Besar. Terlebih disaat malam minggu adalah malam yang sangat ditunggu-tunggu oleh para remaja, dan dimalam minggu itulah yang membuat wisata kuliner pantai Jempol terlihat sangat ramai dari malam-malam sebelumnya. Sehingga wisata kuliner pantai Jempol terlihat sangat ramai dan dipadati oleh orang-orang, baik dari desa-desa maupun dari luar kota yang pergi bermalam mingguan di kota Sumbawa Besar.

\section{Uji Koefisien Determinasi}

Besar nilai koefisien determinasi yang dihasilkan dalam penelitian ini $\mathrm{R}$ square adalah 0,230. Hasil ini menunjukan bahwa pengaruh produk, harga, dan tempat terhadap keputusan pembelian sebesar $23 \%$ dan sisanya $77 \%$ dipengaruhi oleh faktor-faktor lain diluar dari penelitian ini seperti promosi. Dari hasil penelitian $\mathrm{R}$ square sebesar $23 \%$ sangatlah kecil dan diprediksikan sisanya $77 \%$ dipengaruhi oleh faktor promosi.

Menurut dikatakan oleh Kurniawan (2013) bahwa produk, promosi, harga, dan lokasi berpengaruh terhadap keputusan pembelian. Bahwa sebenarnya semua usaha tidak terlepas dari bauran pemasaran yaitu $4 \mathrm{p}$ (product/produk, price/harga, place/tempat, promotion/promosi). $4 \mathrm{p}$ merupakan suatu strategi pemasaran yang digunakan untuk menciptakan pertukaran yang memuaskan tujuan individu dan organisasi.

\section{PENUTUP}

\section{Kesimpulan}

1. Berdasarkan hasil perhitungan yang telah dilakukan secara parsial variabel tidak berpengaruh terhadap keputusan pembelian konsumen, karena dalam penelitian ini, hampir semua jenis produk yang disediakan oleh warung relatif sama antara warung satu dan warung lainnya, sehingga konsumen yang datang ke wisata kuliner pantai Jempol hanya akan berpatokan pada tempat yang nyaman dan pemandangan pantainya, serta harga yang disediakan disetiap warung relatif dapat dijangkau oleh semua kalangan masyarakat.

2. Variabel harga secara parsial berpengaruh terhadap keputusan pembelian konsumen, karena konsumen sangat mempertimbangkan harga sebelum mereka melakukan pembelian suatu barang atau jasa. Harga produk yang ditawarkan di wisata kuliner pantai Jempol sesuai dengan kualitas dan keinginan konsumen akan suatu produk.

3. Variabel tempat secara parsial berpengaruh positif terhadap keputusan pembelian konsumen, karena tempat atau lokasi wisata kuliner pantai Jempol sangat strategis karena berada dipusan keramaian dan berada di pinggiran pantai. Sehingga konsumen yang datang ke tempat kuliner tersebut akan dimanjakan dengan keindahan pemandangan pantai diwaktu sore hari dan angin pantai diwaktu malam hari.

Saran

Bagi peneliti atau pembaca selanjutnya, diharapkan penelitian ini dapat menjadi referensi dan masukan untuk menambah wawasan. Dan diharapkan kepada peneliti selanjutnya untuk dapat menambah jumlah variabel dan jumlah sampel dalam penelitiannya sehingga dapat memberikan informasi terbaru. Dalam penelitian ini, diperoleh hasil penelitian bahwa produk tidak memengaruhi keputusan pembelian konsumen, hal ini tidak sesuai dengan teori maupun hasil penelitian sebelumnya. Diharapkan bagi peneliti selanjutnya, dapat menjadi bahan rujukan penelitian untuk mengetahui lebih dalam penyebab produk tidak memengaruhi keputusan pembelian.

Bagi pemilik usaha yang ada di wisata kuliner pantai Jempol agar dapat meminimalisir permasalahan terhadap variabel produk yang dimana hasilnya tidak perpengaruh terhadap keputusan pembelian dalam penelitian ini. Berdasarkan fenomena yang terjadi dalam penelitian ini bahwa produk tidak berpengaruh terhadap keputusan pembelian dikarenakan hampir semua jenis produk yang disediakan oleh warung relatif sama antara warung satu dengan warung lainnya. Maka dari itu pemilik usaha harus mampu menciptakan inofasi baru terhadap produk yang akan dijual di tempat usahanya, seperti menciptakan produk baru yang tidak ada ditemui di warung-warung lainnya yang ada di wisata kuliner pantai Jempol. Agar dapat menarik minat konsumen terhadap produk baru tersebut. 


\section{DAFTAR PUSTAKA}

Achidah, Nur., Mukery, Warso., Leonardo, Budi, Hasiolan. (2016). Pengaruh Promosi, Harga, dan Desain Terhadap Keputusan Pembelian Sepeda Motor Mio Gt. Journal Of Management, Vol. 2 No.2 Maret 2016. Hal: 8.

Anshori, Muslich dan Iswati, Sri. (2006). Metodologi Penelitian Kuantitatif. Surabaya: Airlangga.

Gitosudarmo, Indriyo. (2000). Manajemen Pemasaran. (Edisi pertama). Yogyakarta: BPFE.

Hariadi, Doni. (2012). Pengaruh Produk, Harga, Promosi Dan Distribusi Terhadap Keputusan Pembelian Konsumen Pada Produk Projector Microvision. Jurnal Ilmu dan Riset Manajemen Vol.1 No.8, 2012.

Hariyati, Ratih. (2005). Bauran pemasaran dan loyalitas konsumen. (Edisi pertama). Bandung: Alfabeta.

Hasan, Ali. (2014). Marketing dan Kasus-Kasus Pilihan. Cetakan kedua, Yogyakarta: CAPS.

Jilly, Bernadette, Mandey. (2013). Promosi, Distribusi, Harga Pengaruhnya Terhadap Keputusan Pembelian Rokok Surya Promild. Jurnal EMBA. Vol.1 No.4 Desember 2013, Hal: 95-104

Kodu, Sarini, (2013). Harga, Kualitas Produk Dan Kualitas Pelayanan Pengaruhnya Terhadap Keputusan Pembelian Mobil Toyota Avanza. Jurnal EMBA. Vol.1 No.3 September 2013, Hal: 1251-1259.

Kurniawan DA (2013). Analisis Pengaruh Produk, Promosi, Harga dan Tempat Terhadap Keputusan Pembelian. (SKRIPSI). Semarang. Universitas Diponegoro.

Kotler, Philip dan Armstrong, Gary. (2010). Priciples of Marketing. Edisi 9. New Jersey: Prentive Hall Inc.

Kotler, Philip dan Keller, Kevin. (2007). Manajemen Pemasaran. Edisi 12. Jilid Pertama dan Kedua. Jakarta: PT. Indeks.

Kotler, Philip dan Kevin Keller. (2009). Manajemen Pemasaran. Edisi 13. Jilid Pertama. Mataram: Erlangga.

Kotler, Philip dan Kevin Keller. (2009). Manajemen Pemasaran. Edisi 13. Jilid kedua. Mataram: Erlangga.

Ligia, Agnes PW., Mananeke, Lisbeth., Sepang, Jantje. (2014). Pengaruh Kualitas Produk, Harga, Promosi Dan Lokasi
Terhadap Keputusan Pembelian Konsumen Di Bentenan Center Sonder Minahasa. Jurnal EMBA. Vol.2 No.3 September 2014, Hal. 1737-1749

Machfoedz, Mahmud, (2010). Komunikasi Pemasaran Modern. Cetakan Pertama, Yogyakarta: Cakra Ilmu.

Malau, Harman. (2016). Manajemen Pemasaran. Bandung: Alfabeta.

Payne, A . (2007). Pemasaran Jasa. Cetakan Kedua. Terjemahan oleh Andi. Yogyakarta: Pearson Education.

Sanusi, Anwar. (2011). Metodologi Penelitian Bisnis. Malang: Selemba Empat.

Siagian, Dergibson., Sugiarto. (2006). Metode Statistika untuk Bisnis dan Ekonomi. Jakarta: Gramedia Pustaka Utama.

Siregar, Syofian. (2013). Metode penelitian Kuantitatif. Edisi pertama. Jakarta: Kencana.

Sriyadi. (1991). Bisnis Manajemen Perusahaan Modern. Semarang. Consumer Behavior.(Edisi ke 10), London: Prentice Hall.

Subagyo Ahmad, 2010. Marketing In Bussiness. Edisi Pertama. Jakarta: Mitra Wacana Media.

Sugiyono. (2009). Metode Penelitian Administrasi. Bandung: Alfabeta.

Sunyoto, Danang. (2011). Metodologi Penelitian Ekonomi. Yogyakarta: CAPS.

Tampi, Danil., Agus, Supandi, Soegoto., Jacky, Sumarauw, SB. (2016). Pengaruh Kualitas Produk, Harga, Dan Daya Tarik Iklan Terhadap Keputusan Pembelian Sepeda Motor Honda Scoopy Pada Pt. Daya Adicipta Wisesa. Jurnal EMBA Vol.4 No.1 Maret 2016, Hal. 990-999

Tandjung, Jenu Widjaja. (2004). Marketing Manajemen : Pendekatan Pada Nilai-nilai Pelanggan. Edisi Kedua. Cetakan Kedua. Malang: Banyu Media Publising.

Tjiptono, Fandy. (2010). Pemasaran Strategik. Yogyakarta: Andi.

Tjiptono, Fandy. (2008). Strategi Pemasaran. Edisi Ketiga. Yogyakarta: Andi.

Tjiptono, Fandy. (1997). Strategi Pemasaran. Edisi kedua. Yograkarta: Andi.

Widiyantoro, Ibnu. (2008). Pointer: Metodologi Penelitian. Semarang: BP UNDIP. 